\title{
Writing Strategy and Factors Contributing to EFL University Students' Preference
}

\author{
Atik Umamah \\ Universitas Islam Malang \\ atikumamah@unisma.ac.id \\ Ika Hidayanti \\ Universitas Islam Malang \\ ikahidayanti@unisma.ac.id
}

\begin{abstract}
This study was aimed to identify 1) the significant difference on the learning strategy attainment by male and female students, 2) the significant difference on the use of the strategies in learning writing based on the students' attitude toward English writing "like or dislike", and 3) the correlation between learning strategy use and three factors: gender, interest and writing achievement. To elicit research data, a-70 item questionnaire was administered to101 English students of Universitas Islam Malang. Ex-post facto and correlation analysis were designs adopted to deal with the problems proposed in this research. The statistical analysis indicated that female students did not deploy the strategies significantly different from the male counterparts. The second finding revealed that the more interested the students in English writing, the more likely they employed the learning strategies. The last report showed that there was no correlation between writing strategy and two factors: gender and writing achievement. Meanwhile, negative-moderate correlation was found between the strategy choice and the students' liking for English writing.
\end{abstract}

Keywords: learning strategy, writing, gender, interest, proficiency

\section{BACKGROUND}

Learning strategies, according to Oxford (1990), refer to "specific actions taken by the learner to make learning easier, faster, more enjoyable, more self-directed, more effective, and more transferrable to new situations" (p.80). It is undeniable that in the context of EFL learning, deploying learning strategies will benefit learners to overcome their difficulties. Anitah, et.al. (2008) argue that the use of strategies could benefit language learners as it gives significant impact toward their learning English achievement. Among the four skills, writing is considered as one way to express and measure someone's English ability; however, it is regarded as the complicated skill which involves many aspects on one's motivation, cognition, and social side (Raoofi, et. al., 2014).

Every learner has different aspects in terms of age, intelligence, motivation, aptitude, attitude, personality, and cognitive styles; those factors distinguish students' ways of learning, specifically in learning a second or foreign language (Skehan, 1989 cited in Anitah, et.al., 2008). Beside the individual aspects, gender is also linked to such circumstance. Thus, the selection of ways on learning would greatly affects the students' success in second language learning (Brown, 2007).

Regarding with the teaching four English skills, writing is seen to be the most difficult skill to acquire (Cahyono \& Widiati, 2011:69). There are several aims for teaching 
writing including "writing for reinforcement, training, imitation, communication, fluency, and learning" (Raimes, 1987:36 in Cahyono and Widiati, 2011: 70). According to Brown (2007), writing needs micro and macro skills. The first skill requires students master the ability to understand the language structure and vocabulary to express the meaning. The latter relates to language learners' ability to comprehend the communicative, cohesive and rhetorical functions in writing English.

There are some models of writing concerning about the teaching techniques that involve 'writing as product', 'writing as process', and 'writing as social activity' (Miller, 1998: 341-344 in Cahyono and Widiati, 2011: 72). Writing as product refers to the student's final writing; writing as process consists of some steps of prewriting, drafting, revising, and editing (Gebhard, 1996). Meanwhile, writing as social activity relates to as "an act of communication between writer and reader within an external context" (Miller, 1998: 343 in Cahyono and Widiati, 2011: 74). As a foreign language, producing good writing is seen as complicated process. Moreover, it is limited to time facility when students are not given enough time to practice the writing. Besides, the lack of English vocabulary is also influential to fluently produce writing. To cope with such difficulties, learners should identify and be aware of some ways to ease them learn writing (Cohen \& Macaro, 2007).

There are a lot of studies talking about the use of learning strategies to develop the writing skill. In some other sides there have been also studies about the learning strategies deployment and the student's writing proficiency, and often correlates to gender. Oxford (1990) and Kaylani (1996) found that female learners deployed more language learning strategies and get more success than male learners. Similar finding was also confirmed by Aslan (2009). According to this research, female learners not only deployed more learning strategies but also got higher achievement than males. Besides, he found that there was significant correlation between gender, language learning and English achievement. In Tehran, Kaivanpanah, et. al. (2012) examined the effect of proficiency and gender to the students' communication strategies. It is reported that the language achievement did not give influence to the students' intensive use of learning strategies. Meanwhile, some communication strategies such as asking for clarification, comprehension check, etc. were implemented differently by the two gender.

In the following year, Radwan (2014) investigated the effects of second language proficiency and gender on the language learning strategies choice in Oman. It was found out that the students mostly deployed the metacognitive strategies and used memory strategies least significantly. In terms of proficiency, the skilled students preferred to use cognitive, metacognitive, and affective strategies compared to less skilled students. The overall strategy use indicated that there was no significant difference between male and female students. Male students used more social strategies, followed by memory, cognitive and metacognitive strategies respectively than female students.

Prior to the learning strategy deployment, this current study distinguishes its research instrument that is the Posteriori Taxonomy of Strategies of Learning English Writing Skill (Mistar, Zuhairi, Parlindungan, 2014) rather than using SILL. The latest strategy taxonomies were categorized into twelve strategy classifications of selfmonitoring, language-focusing, planning, metacognitive affective, cognitive compensation, 
self-evaluating, social process-focusing, authentic practicing, meaning-focusing strategies, vocabulary developing, metacognitive commencement, and mental processing strategies.

In this research, the interest refers to the student's liking for writing English; like or dislike. Interest to writing English influences significantly to the students' choice of the learning strategies (Lan \& Oxford, 2003). Some studies reported that the students who like to writing English will gain much use of the learning strategies than those who dislike it. Based on the review above, the research problems are formulated as follows:

1. Is there any significance difference between the use of learning strategies in writing and gender?

2. Is there any significance difference between the use of learning strategies in writing and students' interest?

3. Does the use of the learning strategy correlate with gender, interest and writing proficiency?

\section{METHOD}

This research employed ex-post facto and correlation designs. The first was aimed to know the difference on the strategy employment by female and male learners. The latter was purposed to identify the correlation between the choice of the learning strategy and the three factors: gender, interest, and writing achievement. The study involved 101 fourth semester students of English Department of Universitas Islam Malang. The fundamental consideration of the subject selection was that they have acquired writing course for about two years at university, so it can be assumed that they had sufficient experience in writing.

The students were asked to answer 70 items of questionnaire which was adopted from Posteriori Taxonomy of Strategies of Learning English Writing Skill (Mistar, Zuhairi dan Parlindungan, 2014). The questionnaire was aimed to gain information on the students learning strategy choice, their different gender, and the students' different interest to writing English.

Utilizing SPSS 20 (Pallant, 2011), the data were analysed using independent t-test to know the significance difference on the the learning strategy deployment by two groups of gender and different interest to writing English. Besides, correlational statistics was also used to find the relationship between the learning strategy use and some aspects such as gender, interest, and writing proficiency. Having been analysed, the correlation was interpreted large if the $\mathrm{r}=.50$ to 1.0 or $\mathrm{r}=-.50$ to -.1 .0 , medium if the $\mathrm{r}=.30$ to .49 or $\mathrm{r}=-.30$ to -.49 , and small if the $\mathrm{r}=.10$ to .29 or $\mathrm{r}=-.10$ to -.29 (Cohen, 1988 cited in Pallant, 2011).

\section{FINDINGS}

\section{Difference in the Use of Learning Strategies in Writing by Male and Female Students}

The summary for statistical analysis using t-Test is presented in Table 1. It reveals that among twelve categories, female deployed six strategies for its higher mean that involve strategy of self-monitoring, authentic-practicing, social process-focusing, language-focusing, planning, and self-evaluating and male also used the latter six including strategies of meaning-focusing, metacognitive commencement, cognitive compensation, mental processing, metacognitive affective, and vocabulary developing. Surprisingly, the overall use of strategy classifications did not significantly differ between the two gender. 
Table 1 The Difference in the Use of Strategies of Learning Writing by Female Students $(\mathrm{N}=85)$ and Male Students $(\mathrm{N}=16)$

\begin{tabular}{|c|c|c|c|c|}
\hline Strategy Categories & Gender & $\begin{array}{c}\text { Mean } \\
\text { (S.D) }\end{array}$ & $\begin{array}{c}\text { Mean } \\
\text { Difference }\end{array}$ & t-value*) \\
\hline \multirow[t]{2}{*}{ Self-Monitoring Strategies } & Female & $3.64(.47)$ & .18 & $1.346(p<.181)$ \\
\hline & Male & $3.46(.58)$ & & \\
\hline \multirow[t]{2}{*}{ Language-Focusing Strategies } & Female & $3.40(.44)$ & .01 & $-.066(p<.948)$ \\
\hline & Male & $3.41(.69)$ & & \\
\hline \multirow[t]{2}{*}{ Planning Strategies } & Female & $3.63(.49)$ & .01 & $.075(p<.940)$ \\
\hline & Male & $3.62(.53)$ & & \\
\hline \multirow[t]{2}{*}{ Metacognitive Affective Strategies } & Female & $3.62(.60)$ & -.03 & $-.166(p<.869)$ \\
\hline & Male & $3.65(.44)$ & & \\
\hline \multirow[t]{2}{*}{ Cognitive Compensation Strategies } & Female & $3.12(.66)$ & -.11 & $-.700(p<.485)$ \\
\hline & Male & $3.23(.57)$ & & \\
\hline \multirow[t]{2}{*}{ Self-Evaluating Strategies } & Female & $3.73(.55)$ & .1 & $.659(p<.512)$ \\
\hline & Male & $3.63(.61)$ & & \\
\hline \multirow[t]{2}{*}{ Social Process-Focusing Strategies } & Female & $3.58(.44)$ & .13 & $1.036(p<.303)$ \\
\hline & Male & $3.45(.43)$ & & \\
\hline \multirow{2}{*}{ Authentic Practicing Strategies } & Female & $2.75(.70)$ & .18 & $.868(p<.387)$ \\
\hline & Male & $2.57(.85)$ & & \\
\hline \multirow[t]{2}{*}{ Meaning-Focusing Strategies } & Female & $3.18(.50)$ & -.18 & $-1.293(p<.199)$ \\
\hline & Male & $3.36(.48)$ & & \\
\hline \multirow[t]{2}{*}{ Vocabulary Developing Strategies } & Female & $3.36(.54)$ & -.02 & $-.154(p<.878)$ \\
\hline & Male & $3.38(.53)$ & & \\
\hline Metacognitive Commencement & Female & $3.17(.49)$ &.-11 & $-.854(p<.395)$ \\
\hline Strategies & Male & $3.28(.51)$ & & \\
\hline \multirow[t]{2}{*}{ Mental Processing Strategies } & Female & $3.49(.49)$ & -.04 & $-.290(p<.772)$ \\
\hline & Male & $3.53(.58)$ & & \\
\hline
\end{tabular}

\section{Difference on the Use of Learning Strategies of Writing by The Students Who Have Different Interest/Liking}

Table 2 clearly defines the result from t-Test statistical analysis. It shows that the students who like to write English used the overall learning strategies in writing differently and significantly from the students who dislike the English. Besides, ten strategy categories were significant at the level of .05 , and the rest two strategies were above the Sig ( 2 tailed) value .117 for planning strategies and .116 for authentic-practicing strategies. This implies that the students who like English use the learning strategies effectively and significantly different from the students who dislike English.

Table 2 The Difference in the Use of Strategies of Learning Writing Skill for different Interest: students who like $(\mathrm{N}=54)$ and students who dislike $(\mathrm{N}=47)$

\begin{tabular}{llccc}
\hline \multicolumn{1}{c}{ Strategy Categories } & Gender & $\begin{array}{c}\text { Mean } \\
\text { (S.D) }\end{array}$ & $\begin{array}{c}\text { Mean } \\
\text { Difference }\end{array}$ & t-value*) \\
\hline Self-Monitoring Strategies & Like & $3.75(.47)$ & .30 & $3.104(p<.002)$ \\
& Dislike & $3.45(.47)$ & & \\
Language-Focusing Strategies & Like & $3.55(.53)$ & .32 & $3.552(p<.001)$ \\
& Dislike & $3.23(.36)$ & & \\
Planning Strategies & Like & $3.70(.44)$ & .15 & $1.583(p<.117)$ \\
& Dislike & $3.55(.54)$ & & \\
\hline
\end{tabular}




\begin{tabular}{|c|c|c|c|c|}
\hline \multirow[t]{2}{*}{ Metacognitive Affective Strategies } & Like & $3.81(.48)$ & .40 & $3.665(p<.000)$ \\
\hline & Dislike & $3.41(.61)$ & & \\
\hline \multirow{2}{*}{ Cognitive Compensation Strategies } & Like & $3.24(.63)$ & .22 & $1.956(p<.053)$ \\
\hline & Dislike & $3.02(.51)$ & & \\
\hline \multirow[t]{2}{*}{ Self-Evaluating Strategies } & Like & $3.87(.56)$ & .33 & $3.091(p<.003)$ \\
\hline & Dislike & $3.54(.51)$ & & \\
\hline \multirow[t]{2}{*}{ Social Process-Focusing Strategies } & Like & $3.69(.41)$ & .28 & $3.317(p<.001)$ \\
\hline & Dislike & $3.41(.43)$ & & \\
\hline \multirow[t]{2}{*}{ Authentic Practicing Strategies } & Like & $2.82(.67)$ & .22 & $1.585(p<.116)$ \\
\hline & Dislike & $2.60(.77)$ & & \\
\hline \multirow[t]{2}{*}{ Meaning-Focusing Strategies } & Like & $3.38(.46)$ & .37 & $3.924(p<.000)$ \\
\hline & Dislike & $3.01(.47)$ & & \\
\hline \multirow[t]{2}{*}{ Vocabulary Developing Strategies } & Like & $3.47(.54)$ & .23 & $2.141(p<.035)$ \\
\hline & Dislike & $3.24(.51)$ & & \\
\hline Metacognitive Commencement & Like & $3.30(.47)$ & .24 & $2.442(p<.016)$ \\
\hline Strategies & Dislike & $3.06(.49)$ & & \\
\hline \multirow{2}{*}{ Mental Processing Strategies } & Like & $3.61(.50)$ & .35 & $2.488(p<.015)$ \\
\hline & Dislike & $3.36(.47)$ & & \\
\hline
\end{tabular}

\section{The Use of learning strategies in Writing Correlated with Gender, Interest and Writing Achievement.}

The statistical result indicated that there is no correlation between the strategy use and gender $(\mathrm{r}=.013)$. The finding also confirms that the use of learning strategy did not correlate to the students' writing achievement $(\mathrm{r}=-.055)$. Meanwhile, a medium negative relationship was gained between the students' interest and the strategy deployment $(\mathrm{r}=-$ .414). To sum up, these findings show that the overall use of strategy of learning writing did not significantly correlate with the terms of gender and writing achievement; however, the learning strategy use relates to the students' interest with a negative medium level.

\section{DISCUSSION}

As it has been stated previously, there are three research findings regarding with the learning strategy categories in writing. The first finding indicates that the overall use of the learning strategies did not show significant different from both gender. In relation to the students' preference, it was found that the more interested students the more they apply the learning strategies in writing. Then the correlation analysis resulted that there was no correlation between the strategy choice and the students gender and their proficiency in writing. Meanwhile, the learning strategy deployment only correlates with the learners' interest in negative medium level.

Regarding with the learning strategy use, female preferred to choose selfmonitoring strategies, planning, language-focusing, self-evaluating, social-processing, and authentic-practicing strategies. They had good and arranged planning before producing an English text. To gain ideas, they read many articles and collected information on the related topic from some sources. Then they made mind-mapping to generate their ideas before making an outline. As soon as it has been outlined, they start writing the rough draft and making some revisions on their written product. Besides, they concerned about the use of right sentence structures and effective vocabulary to get a good produced text. Furthermore, the female students tend to have more communication with others like teachers and classmates. In this case they like to ask their friends to correct their product. 
In opposite, male learners preferred to use the learning strategies of metacognitive affective, cognitive compensation, meaning focusing, vocabulary developing, metacognitive commencement and mental processing strategies. Here, male students tried to feel relax when they are afraid of making mistakes in writing. To understand some new English vocabulary, they sometimes translate them into Indonesian. Before writing, they jot down some new words and make up some notes. The insignificant difference on the learning strategy choice used by the two genders was confirmed by Radwan (2014) and Kaivanpanah, et.al. (2012). But, the present result was not supported by Oxford (1990); Kaylani (1996); and Aslan (2009) who found that female learners tend to deploy the learning strategies than male students.

In terms of the interest, the students who like English much, gained more use of the learning strategies and it was significantly different from the students who dislike to writing English. Out of twelve strategy categories, ten strategy categories were significant at the level of .05 , and the rest two strategies were above the Sig (2 tailed) value .117 for planning strategies and .116 for authentic-practicing strategies. This result supports Lan and Oxford (2003) who found that the students who like to English tend to deploy more learning strategies. Meanwhile, the correlation between the strategy choice and gender and writing achievement did not show significant correlation. Indeed, the strategy attainment has negative medium correlation with the students' liking to English. This does not confirm with the studies conducted by Aslan (2009) who found the significant correlation between the learning strategy and gender and English achievement.

\section{CONCLUSION}

The current study found that the overall learning strategy attainment was not used significantly different by the two genders. It is in contrast with the interest toward English where the more the students like to English the more they deploy the strategies in writing. Further result indicates that the use of strategies did not correlate with gender and writing achievement; however, the negative medium correlation was found between the learning strategies and the students' interest toward writing English. Pedagogically, this research results imply the need to implement strategy-based instruction for EFL students, especially in learning writing. Recognizing the prominent role of learning strategies and the effective strategies applied by successful learners, students are expected to get appropriate solution to deal with some writing problems. 


\section{REFERENCES}

Anitah, W. S., Setyadi, Ag. B., \& Mistar, J. (2008). Strategi pembelajaran bahasa Inggris. Jakarta: Penerbit Universitas Terbuka.

Aslan, O. (2009). The role of gender and language learning strategies in learning English. The Graduate School of Social Sciences of Middle East Technical University. Retrieved from www.citeseerx.ist.psu.edu

Brown, H. D. (2007). Teaching by principles: An interactive approach to language pedagogy (3rd ed.). New York: Pearson Education, Inc.

Cahyono, B.Y \& Widiati, U. (2011). The Teaching of English as a Foreign Language in Indonesia. Malang: State University of Malang Press.

Cohen, A.D \& Macaro, E. (2007). Language Learner Strategies. Oxford: Oxford University Press

Gebhard, J.G. (1996). Teaching English as a Foreign or Second Language: A Teacher Self-development and Methodology Guide. The University of Michigan Press

Kaivanpanah,S., Yamouty, P \& Karami, H. (2012). Examining the effects of proficiency, gender, and task type on the use of communication strategies. Porta Linguarium, 17, 79-93.

Kaylani, C. (1996). The Influence of Gender and Motivation on EFL Learning Strategy Use in Jordan. In R. L. Oxford (Ed.), Language Learning Strategies around the World: Cross-Cultural Perspectives (pp. 75-88). Honolulu. University of Hawaii Press.

Lan, R. \& Oxford, R. L. (2003). Language learning strategy profiles of elementary school students in Taiwan. IRAL, 41, 339-379.

Mistar, J., Zuhairi, A., Parlindungan, F. (2014). Strategies of learning English writing skill by Indonesian senior high school students. Arab World English Journal, 5(1), 290303.

Oxford, R. L. (1990). Language learning strategies: What every teacher should know. New York: Newbury House Publishers.

Pallant, J. (2011). SPSS survival manual: a step by step guide to data analysis using SPSS (4th ed.). Crows Nest, NSW: Allen \& Unwin.

Raoofi, S., Chan, S.H., Mukundan, J., Rashid, S. Md. (2014). A qualitative study into L2 writing strategies of university students. English Language Teaching, 7(11),

Radwan, A.A. (2014). Effects of L2 proficiency and gender on choice of language learning strategies by university students majoring in English. Arab World English Journal, $5(1), 21-32$. 